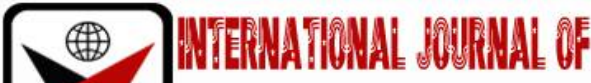

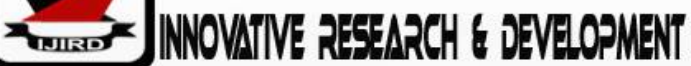

ISSN 2278 - 0211 (Online)

\section{Effect of Public Debt Service on Economic Growth in Kenya: Vector Error Correction Model (VECM) Approach}

\author{
Francis Sirare Marwa \\ Assistant Manager, Department of Finance, Kenya Bureau of Standards, Nairobi, Kenya
}

\begin{abstract}
:
The study examined relationship between debt servicing and GDP growth in Kenya from 1980-2017. The study embraced the VECM to analyze data. The variables in the research comprised of RGDP, external debt service (EDS) and domestic debt service (DDS). The outcome exhibited that foreign debt service has a deleterious association with GDP growth. Domestic debt service has a substantial positive influence on GDP growth in Kenya. There is causality running from domestic debt service to RGDP. The inference of the outcome pinpointed that foreign debt service has deleterious "outcome on "GDP" growth in Kenya and therefore not good for economic growth. Based on these findings the government should manage the acquisition of state borrowing in the most effective and efficient way by ensuring that borrowed funds are channeled to intended capital projects that can lead the country to achieve desire economic prosperity and stability.
\end{abstract}

Keywords: Public debt service, economic growth, external debt service, domestic debt, real gross domestic product

\section{Background of the Study}

Developing nations use government borrowing as a vital tool to finance fiscal deficit. This is because tax revenues in these countries lag behind public expenditure thus fiscal deficit. Economic growth can be achieved in developing countries by proficient utilization of borrowed fund if at all the funds are used for development projects such as roads and other infrastructure. The creation of modern transport infrastructure for instance will support the expansion of a country's national output leading to economic growth. However, if public debt is not properly managed it can restrict economic growth and become a burden to developing countries and to high inflation and high interest rate and possibly tax increases in future (Ezeabasili, \& Mojekwu, 2011).

Total public debt in Kenya was Ksh 459.5 Million by the end of June 2018 translating to a growth of $49 \%$ compared to end of June 2017 where public debt service was Ksh 308.5 Million. Foreign and local debt service stood at "Ksh.220.6" Million and "Ksh 239.5" Millions respectively. The foreign debt service was 47.9\% of total debt service cost while domestic debt as percentage of total service cost was $52.1 \%$ as at $30^{\text {th }}$ June 2018 . From the forgoing external debt service has been on the upward trend due to increased external borrowings, while on the other hand, Domestic debt service has been declining. The decline in domestic debt service is in line with government strategy of not borrowing from the local financial markets. Local borrowing by the government could cause serious economic challenges of crowding out the private investors, making available credit to private sector expensive and in the overall interest rate will rise, leading to less than "optimum employment and output in the economy (Republic of Kenya, National Treasury, 2018).

Looking at the public debt service to total revenue collected in Kenya increased to 33.4\% in 2018 compared to 23.6\% in 2017. This increase was attributed to foreign debt stock maturing in 2017/ 2018 financial year.

As at 2018, the total public debt service was $4.1 \%$ of the GDP. External debt service accounted for $1.2 \%$ of GDP, while domestic debt accounted for 1.9\% of GDP (Republic of Kenya, National Treasury, 2018). 


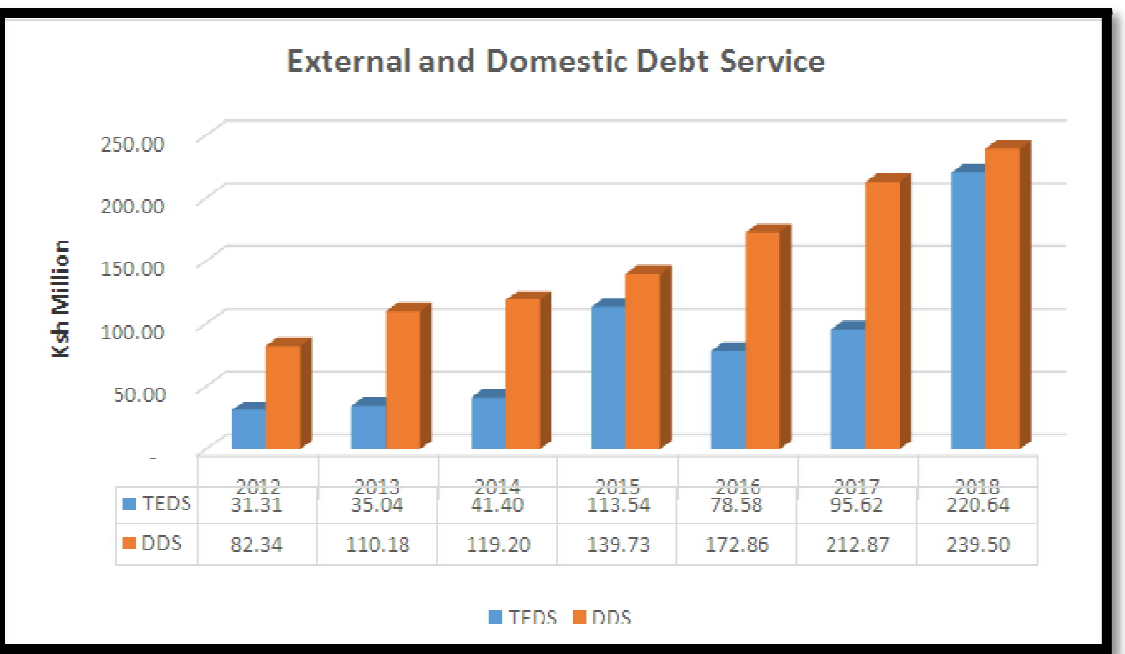

Figure 1: Foreign and Domestic Debt Service

Inferring figure 1.1 above public debt service to total revenue collected in Kenya increased to $33.4 \%$ in 2018 compared to $23.6 \%$ in 2017. This increase was attributed to increase in external debt stock maturing in 2017/2018 financial year.

As at 2018, the total public debt service was 4.1\% of the GDP. External debt service accounted for 1.2\% of GDP, while domestic debt accounted for 1.9\% of GDP ((Republic of Kenya, National Treasury, 2018); Central Bank of Kenya, 2018).

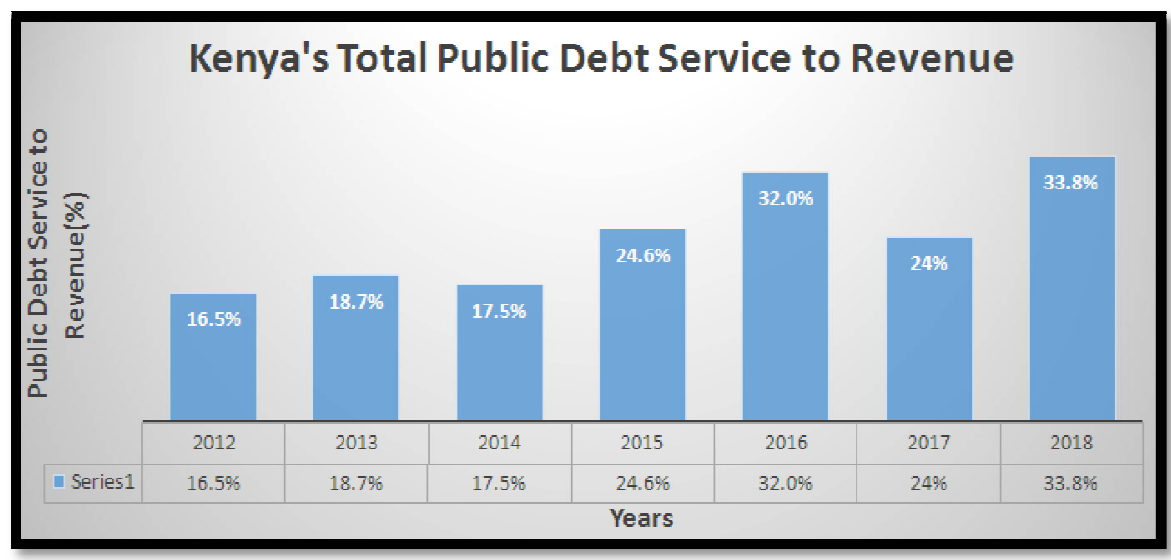

Figure 2: Total Public Debt Service to Revenue

1.1. GDP Growth Rate in Kenya

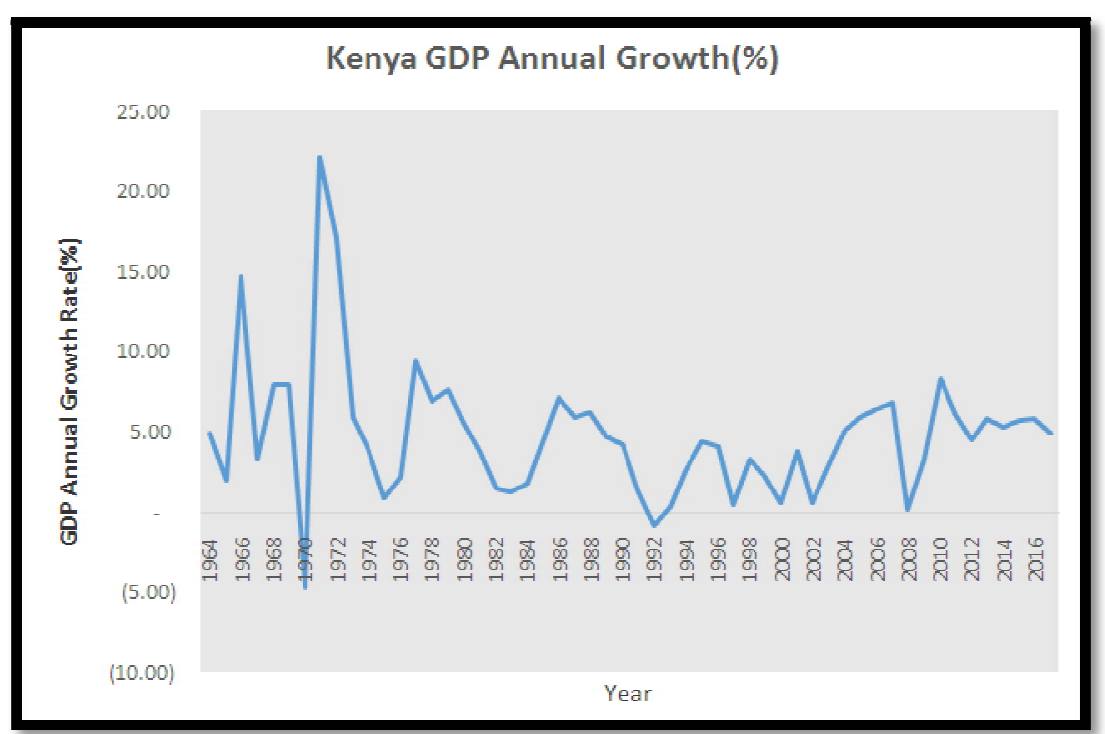

Figure 3: Kenya's GDP Growth Rate 
Kenya experienced a negative economic performance growth of $-4.66 \%$ in 1970. This trend reversed in 1971 where the growth up to $22 \%$ and $17 \%$ in 1972. From 1973, the economic performance declined to $0.88 \%$ in 1975 . From 1991 to 1993 experienced the worst economic performance where the annual growth rate was $1.44 \%$ in 1991 and $-0.8 \%$ in 1992. During this period GDP growth stagnated, agricultural production decreased, inflation hit $100 \%$ and fiscal deficit was greater than $10 \%$ of the GDP (Mwaniki, 2016).

The growth of GDP picked in 2004 and 2005 where the country posted a growth rate of $5.1 \%$ and $5.9 \%$ respectively. The impressive growth in 2004 and 2005 was due to expansion in tourism, telecommunication, transport and construction and recovery of construction sector. "In the year 2007," "the growth rate was 6.85\%" and which "declined in the year " 2008 " to " $0.23 \%$ " due to post election violence." The development rate in 2015 was estimated to be $5.72 \%$, while 2016 the country posted a growth rate of 5.87\%. The slight improvement in GDP growth was due to stable macroeconomic environment, robust improvement in agricultural inputs, growth in construction sector, finance and insurance and real estate (Mwaniki,2016; Otieno, 2015).

\subsection{Statement of the Problem}

Public debt service costs have been on the upward increase. As at 30th June 2018 public debt service in stood at Ksh.459.5 Million which is 150.9 million from Ksh 308.5 Million as at 30th June 2017. The debt service to revenue increased to 33.8 by the end of June 2018 compared to $23.6 \%$ in the year 2017. This means that Kenya spent about $33.8 \%$ of her tax revenue to service public debt. "Looking at cost and risks of total public debt interest payment of public debt stood at "4.1\%" of the "GDP", of which "foreign debt service" and "local debt service" was $1.2 \%$ and $1.8 \%$ of the GDP respectively". In the overall interest cost on total public debt as percentage of revenue collected is $23.9 \%$. "The forex exposure as at $30^{\text {th }}$ June 2018 was high because $50.9 \%$ of total public debt is denominated in foreign currency". The increasing public debt service can affect the development agenda of the government since over $33.4 \%$ of tax revenue will be used for debt servicing. If the floating of public debt in Kenya is not adequately addressed it is likely to lead to financial instability and rescheduling of loan payment. "The objective of this study was to establish the extent to which to which debt service affects GDP growth in Kenya and specifically find out how foreign and local debt service affect the GDP" (Hukkinen \& Viren, 2017; Republic of Kenya, National Treasury,2018)

\subsection{Research Objectives}

The focal point of this research was to establish the connection between government debt service and GDP growth in Kenya.

\subsection{Research Hypotheses}

- $\mathrm{HO}_{1}$ : "External debt servicing does not significantly affect GDP growth in Kenya".

- $\mathrm{H}_{2}$ : "Domestic debt servicing does not significantly affect GDP growth in Kenya".

\subsection{Justification of the Study}

The product of the research will assist stakeholders to understand the association between government debt service and growth and put in place effective measures to enhance the nation's economic growth and stability. The findings will be vital in informing policy on the appropriate and optimal debt mix for the purpose of achieving desirable economic growth outcomes.

Finally the research will add to the frame of knowledge, while at the same time, deepening research gaps on outcomes of high Public debt service on GDP growth that other academicians can undertake in future.

\subsection{Scope of the Study}

The study explored consequences of debt servicing on "GDP growth" in Kenya. The main area of study was public debt," "servicing which consist of foreign debt service and internal debt service. The study applied secondary data from 1980 to 2017. The study applied the use of VAR analysis and VECM. Secondary data was collected in Nairobi, Kenya.

\section{Literature Review}

\subsection{Theoretical Framework}

Over the years, there has been lots of literature on the extent to which government borrowing affects GDP growth. There are three key lines of how statement borrowing touches on GDP growth. The first key line is grounded on Keynesian Theory, which is founded on expansionary fiscal policy, that will lead to rise in fiscal deficit and thus borrowing appetite rises. This line also argue that expansionary fiscal policy will stimulate effective overall demand, leading into stimulation of consumption, investment, employment and GDP growth (Mahmoud, 2015).

The second key line is premised on Ricardo who argue that there is no consequence of government borrowing and fiscal deficits on GDP growth. When there is fiscal stimulation in the economy fiscal deficits and government borrowing increases. Consequently, the country will resort to contractionary fiscal policies by increasing taxes, that in turn reduce purchasing power and consumption levels in the country (Otieno, 2015).

The third key line on government borrowing and GDP growth is founded on crowding out hypothesis. This theory posits that rise in fiscal deficit and government borrowing will lead to reduced GDP growth due to increase in interest rates, reduction in "investment and capital formation," which will eventually slow down GDP growth. According to crowding out hypothesis, a country burdened with high public debt will have weak GDP growth forecasts. The 
consequence of government borrowing on GDP is multi-directional it consists of foreign and domestic debt service. Domestic debt influences negatively the domestic private investment, this due to the reduction in domestic savings that are used to finance public debt instead of providing credit facilities to the private sector (Mencinger et al., 2014; Boldeanu \& Tache, 2016; Allegret et al., 2016).

According to orthodox view of government borrowing, in the short term, output high public debt will have positive influence on GDP growth (Panizza \& Presbitero, 2013). The positive short-run effect of public debt is big when the GDP is far from capacity. Higher public debt will lead to endowment reduction in the country. Lower endowment in the local market will have deleterious impact on the GDP, this is will lead to little capital funds, higher borrowing cost, unemployment and little foreign inflows, and have deleterious effect endowment projects and thus lead to the country's GNI stagnating. Deleterious impact of government borrowing on GDP can result in tax increase, which distorts price level in the economy.

According to Babu, et al. (2015) public debt may have positive and negative impacts on economic growth. From the traditional point of view, budget deficit financed by public debt will have numerous effects on the country. The instant consequence of tax cut will stimulate consumption thus affecting the "economy" in the "short run" and "long run". Higher consumer spending will raise effective demand of commodities and thus raise output and full employment in the economy. As consumption increases, the domestic saving will decrease and domestic savings will fall short of government dis-saving. This will lead to upsurge of cost of credit in the economy creating interest rate arbitrage, attracting foreign capital inflows. In the long-term public debt will lead to increase in interest rates, discouraging investment and thus hinder private investment. The investments from foreign investors will result in higher external debt, and higher effective aggregate demand will lead to higher price levels that adjust over time and the economy output becomes lower. "Reduction in investment will lead to lower steady capital stock and lower level of output". The general influence of government borrowing on the GDP growth will be lower than optimal output, lower consumption, and reduced economic welfare. This is called the burden of public debt as each generation burdens the other by leaving behind small aggregate capital stock (Sheik et al., 2010: Babu et al., 2015).

According to Manik and Khan (2018) the encumbrance of government borrowing is the state of affairs when endowment from government borrowing in form returns are become small due of government debt service commitments. The upsurge of debt service cost will cast doubts in a country's ability to repay off the government debt, and activate tax increase expectation in the future. The doubt of repaying government debt will lead to loss of local and international investments opportunities. "Increase in debt service will lead to lower GDP growth". "The encumbrance of debt implies that government borrowing will be a future tax on "production."

\subsubsection{Debt Overhang Theory}

"The debt overhang theory" "asserts" that if public debt outstrips the country's service capacity in coming days," "then the anticipated service cost of that country will have snowballing effect on the production" (Owusu \& Erickson, 2016). "This infers that proceeds gained from endowing in the local market is taken by the international investors thus depressing local endowments" (Saxena \& Shanker, 2018). "In such a circumstance, the indebted nation is left with a small fraction of any proliferation in production because part of the earning is used to pay foreign borrowings" (Upreti, 2015). On the converse, this theory avows that decreasing borrowing commitment can result into to upsurge in endowment and service capacity. When this happens, the unsettled debt will be paid off thus reducing chances of nonpayment (Hukkinen \& Viren, 2017).

Equally, "when state borrowing is large, the borrowing state is on the incorrect side of the debt Laffer curve". "Debt Laffer curve" depicts state borrowing level and service capacity. This infers that there is an upper limit at which of government borrowing can stimulate growth (Krause \& Moyen, 2016). "Debt overhang theory" envisages that, if there is a chance in future," "that state debt will be larger than the state's service capacity," then this can deter both local and international endowment (Alcidi \& Giovannini, 2015).

Manik and Khan (2018) gave their view on debt overhang theory. They argue that when government borrowing accrues outside bearable frontier, it contracts GDP growth by impending endowment this is referred as debt overhang. Debt overhang underscores that high level of government borrowing will discourage private endowment thus adversely affecting (Liu \& Lee, 2018).

\subsubsection{Dual Gap Analysis Model}

The theory holds the view that developing countries face two autonomous hindrances in achieving specific rate of real economic growth, that is domestic saving and foreign exchange trap.

The two-gap model posits that developing nations face two gaps in their economies, which they will have to fill to realize economic development. The first gap is between domestic savings and private and public investments in the economy. Developing countries have low level of savings and they have to turn around their economies by investing heavily. The second gap is that of export and import. Several developing countries are net importers, since most of them produce primary goods while they require large supply of capital goods, leading to large current- account deficits. This theory asserts that developing countries will fill these gaps by borrowing funds externally in order to realize and accelerate economic growth. According the dual gap hypothesis "external debt promotes economic growth" in a country as long as the borrowed funds are channeled to infrastructural projects. In summary the theory, offers an explanation that investment brings about development and as such that require domestic savings, if the savings are insufficient, the developing countries can borrow from abroad (Al-Zeaud, 2014; Kalemli, Reinhart, \& Rogoff, 2016). 


\subsubsection{Conceptual Framework}

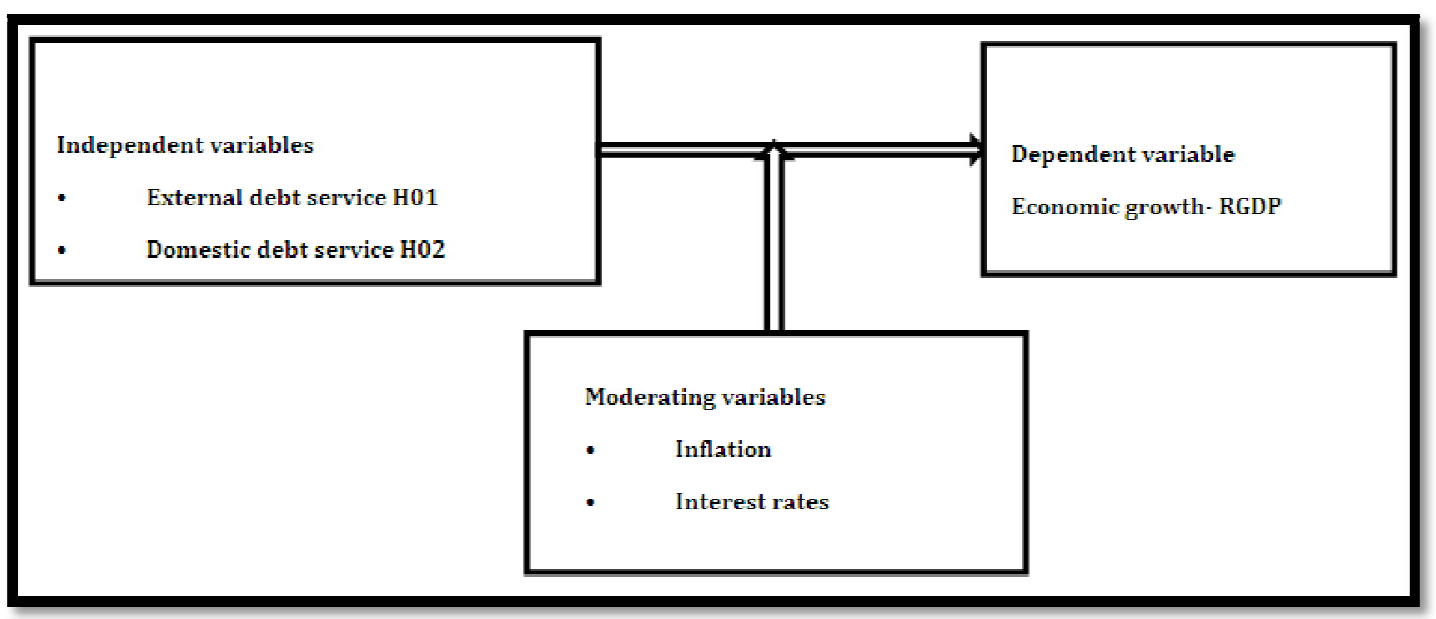

Figure 4: Conceptual Framework

\subsection{Empirical Review}

Nwanne (2018) studied the consequences of foreign debt service on "foreign exchange rate in Nigeria using secondary data from 1981-2013". "The study engaged the use" "Multiple Regression analysis and cointegration analysis" to estimate the "model." "The result of the research showed that", "external debt service has negative relationship with foreign exchange rate", and by extension, has deleterious impact on GDP growth of a country". "The study used foreign debt service as the main variable in the study excluding domestic debt servicing".

Molonko, Jagongo and Omagwa (2018) explored consequences of debt servicing on sect GDP growth in Kenya from 2006-2015. The study employed the use of ARDL model. "They analyzed eleven sectors of the economy that receive government funding." "The outcome of the study demonstrated that debt servicing has a significant consequence on the growth in the country."

Otieno (2015) "opined the connection between debt servicing and GDP in Kenya using secondary data from 19702013." The study adopted regression analysis as a data analysis tool. "The outcome of the study showed that debt servicing has statistically significant impact on GDP growth performance and that debt servicing crowded out investment in Kenya"

Ebi and Imoke (2017) "investigated" "public debt carrying capacity" and "debt transmission channels" in Nigeria using secondary data from 1970- 2014". The research used quadratic function in modelling the various relationships of interest. VECM was also used as data analysis tool. The outcome of the study showed that government borrowing and GDP have positive association. "The study also found that "investment," "interest rates" and "domestic savings being the" "channels through which government borrowing affects GDP growth"

Muli and Ocharo (2018) "deliberated on the outcome of foreign debt service and the current account balance in Kenya." "The study utilized VECM to estimate the relationship among variables." "The study found out that external debt service granger causes current balances in Kenya which indirectly impact GDP in Kenya"

Ryan and Maana (2014) conducted a study on public debt dynamics and sustainability in Kenya using annual time series data from 1983-2013. The study adopted both co-integration and stochastic debt sustainability techniques. They found that public debt in Kenya is sustainable over the period of study

Omotosho, Bawa, and Doguwa (2016) "explored the consequence of foreign debt service and GDP growth in Nigeria using secondary data and employed regression analysis." "The findings of the study demonstrated that foreign debt service has an inverted U-shape relationship with GDP growth." "The implication of foreign debt service it will hurt the economy," since a large "portion of tax revenue goes into payment of external debt." Finally, the study found empirical support for external debt, "if well handled it could promote economic growth in a country."

Mahmoud (2015) discoursed the relationship of foreign debt service on GDP in Mauritania. The study applied regression analysis. The study found out that foreign debt service has a deleterious relationship with GDP in Mauritania.

Abdullahi, Bakar and Hassan (2016) "analyzed the relationship between foreign debt service and capital formation in Sub- Saharan countries." The study applied regression analysis techniques in data analysis. The outcome of the study indicated that external debt service is negatively correlated with GDP in the sub-Saharan countries. They also found that debt service because of external debt could lead to debt overhang in the said countries. Debt overhang will affect negatively development of capital formation, which is an essential determinant of growth.

Siddique and Selvanathan (2015) "examined the consequences of foreign debt service on GDP growth in emerging countries from 1970-2007 using "regression analysis techniques." "The outcome" of the study demonstrated that in the "short-term" and in long- term, external debt service has negative relationship with GDP". This implied that foreign debt stock should be reduced to manageable levels to "spur economic growth in developing countries."

Apergis and Cooray (2016) "explored the connection between GDP and public debt service using data covering the period from 2001-2013 in Eurozone countries by applying the ARDL model in data analysis." The findings established that foreign debt service wields deleterious outcome on GDP across Eurozone countries. 
Cholifihani (2008) "investigated association between public debt service and GDP growth in Indonesia using secondary data from 1980- 2005." The study applied cointegration technique to analyze relationships among variables. The result indicated that debt service could lead to debt over hang and increasing foreign debt service obstruct the GDP negatively. The domestic debt service supports the GDP growth in the country of the study

Karagol (2012) examined debt service burden and capital formation in Turkey using multivariate cointegration techniques to develop VECM essential for highlighting long- term relationship among variables. "The study found that there is unidirectional causality running from debt service to GDP". Submitted that debt service has a deleterious outcome on the GDP growth

Aderoju (2018) "studied the connection between debt service and "GDP growth" in Nigeria using secondary data from 1981-2016." "The study applied ordinary least square technique to estimate results in the study." "The outcome of the research displayed that local debt service has significant effect on growth."

\section{Research Methodologies}

\subsection{Research Design}

This study engaged descriptive research design. Descriptive research design is about finding out the what, the where, and the how of a phenomenon.

\subsection{Target Population}

The study engaged secondary data from 1980 to 2017. "The constituents of public debt service consisted of foreign debt service and domestic debt service".

\subsection{Sample and Sampling Technique}

The sample size for secondary data was secondary data for the period from 1980 to 2017. The secondary data was made up of foreign debt service and local debt service.

\subsection{Data Collection Instruments}

The study employed time series data for the period 1980 to 2017. The secondary data collection form was used to collect secondary data. The form collected foreign debt service and local debt service. The data was collected from Statistical Abstracts from KNBS and CBK Statistical Bulletin.

\subsection{Data Collection Procedure}

Time series data was extracted from Statistical Abstracts and Economic Surveys from "KNBS, Central Bank of Kenya Statistical Bulletin, World Bank and IMF publications". The extracted secondary data was verified and checked for accuracy before recording in secondary data collection forms developed by the researcher.

\subsection{Data Processing and Analysis}

The study employed time series regression analysis on secondary data. Specifically, the VAR analysis and VECM. Stationarity of variables was tested by "ADF test," while "co-integration relationship" among variables, "Johansen cointegration test was applied." The lag length for the models was determined by lag selection criteria such as "LR," "FPE," "AIC," "SIC" and "HQ." "The lag length selection criteria that returns the lowest value will selected".

According to Shrestha and Bhatta (2018) "argue that applying appropriate data analysis methodology for time series data was the critical part of the time series analysis as wrong technique can result in biased and unreliable estimates". The estimation was done as indicated: "stationarity of secondary data was established by the use of ADF unit root test." This was be necessary to "avoid having spurious regression" "results and determine whether variables under study were stationary or non-stationary." "The existence of cointegration among variables was tested by the use of Johansen Cointegration test." "The long-run relationship among variables was estimated by VECM model".

$\operatorname{lnRGDP} t=\beta_{0}+\beta_{1} \operatorname{lnRGDP}_{t-1}+\beta_{2} \operatorname{lnDDS}_{\mathrm{t}-1}+\beta_{3} \operatorname{lnEDS}_{\mathrm{t}-1}+\mathrm{U}_{\mathrm{t}} \ldots \ldots . . \mathrm{EQ1}$

Public debt service model, equations in VECM form was specified as follows:

$\Delta \ln \mathrm{RGDP}_{\mathrm{t}}=\beta_{0}+\beta_{1} \Delta \operatorname{lnRGDP} \mathrm{t}-1+\beta_{1} \Delta \operatorname{lnDDS}_{\mathrm{t}-1}+\beta_{2} \Delta \operatorname{lnEDS}_{\mathrm{t}-1}+\mathrm{ECT}_{\mathrm{t}-1}+\mathrm{U}_{\mathrm{t}} \ldots \ldots . . \mathrm{EQ} 2$

Where:

RGDP = "Real Gross Domestic product"

DDS="Domestic Debt service"

EDS= "External Debt Service"

$\mathrm{ECT}=$ "Error Correction Term"

$\Delta=$ "Difference Operator" 


\section{Presentation of Results}

\begin{tabular}{|c|c|c|c|c|}
\hline Series & ADF Test Statistic & $\mathbf{5 \%}$ Critical Value & $\mathbf{1 0 \%}$ Critical Value & Remarks \\
\hline LNEDDS & -1.532436 & -2.918778 & -2.597285 & Not-stationary \\
\hline LNBEDT & 1.021097 & -2.91765 & -2.596689 & Not-stationary \\
\hline First Difference & & & & \\
\hline Series & ADFTest Statistic & $5 \%$ Critical Value & $10 \%$ Critical Value & Remarks \\
\hline D(LNGDP) & 1.021097 & -2.918778 & -2.597285 & Stationary \\
\hline D(LNBEDT) & -9.800785 & -2.918778 & -2.597285 & Stationary \\
\hline
\end{tabular}

Table 1: ADF TEST (Series at Level and First Difference)

\begin{tabular}{|c|c|c|c|c|}
\hline $\begin{array}{c}\text { Hypothesized No. } \\
\text { of CE(s) }\end{array}$ & Eigenvalue & Trace Statistic & 5\% Critical Value & Prob** \\
\hline None* & 0.321685 & 33.57319 & 29.79707 & 0.0175 \\
\hline At most 1 & 0.214646 & 13.38976 & 15.49471 & 0.1013 \\
\hline At most 2 & 0.01575 & 0.825499 & 3.841466 & 0.3636 \\
\hline $\begin{array}{c}\text { "Hypothesized No. } \\
\text { of CE(s)" }\end{array}$ & "Eigenvalue" & "Max-Eigen Statistic" & "5\% Critical Value" & Prob** \\
\hline None* & 0.321685 & 20.18343 & 21.13162 & 0.0674 \\
\hline At most 1 & 0.214646 & 12.56426 & 14.2646 & 0.0912 \\
\hline At most 2 & 0.01575 & 0.825499 & 3.841466 & 0.3636 \\
\hline
\end{tabular}

Table 2: Unrestricted Cointegration Rank Test (Trace) and Maximum Eigen Test Results

\begin{tabular}{|c|c|c|c|c|}
\hline $\begin{array}{c}\text { Hypothesized No. of } \\
\text { CE(s) }\end{array}$ & Eigenvalue & Trace Statistic & 5\% Critical Value & Prob** \\
\hline None* & 0.321685 & 33.57319 & 29.79707 & 0.0175 \\
\hline At most 1 & 0.214646 & 13.38976 & 15.49471 & 0.1013 \\
\hline At most 2 & 0.01575 & 0.825499 & 3.841466 & 0.3636 \\
\hline Hypothesized No. of CE(s) & Eigenvalue & Max-Eigen Statistic & $5 \%$ Critical Value & Prob** \\
\hline None* & 0.321685 & 20.18343 & 21.13162 & 0.0674 \\
\hline At most 1 & 0.214646 & 12.56426 & 14.2646 & 0.0912 \\
\hline At most 2 & 0.01575 & 0.825499 & 3.841466 & 0.3636 \\
\hline
\end{tabular}

Table 3: Normalized Long-Run and Short-Run Cointegrating Coefficient

\begin{tabular}{|c|c|c|c|c|}
\hline Cointegrating Eq & CointEq1 & Standard error & t-Statistics & Prob. \\
\hline LNRGDP(-1) & 1 & & & \\
\hline LNDDS(-1) & -1.05138 & 0.20754 & 5.065929 & 0.0001 \\
\hline LNEDS(-1) & 1.214582 & 0.2809 & 4.323895 & 0.0035 \\
\hline C & -15.24775 & & & \\
\hline & $\begin{array}{c}\text { Vector Error } \\
\text { Estimates }\end{array}$ & & \\
\hline Variables & Coefficient & Std. Error & t-Statistic & Prob. \\
\hline ECT(1) & -0.020881 & 0.010543 & -1.980555 & 0.0481 \\
\hline LNRGDP(-1) & 0.142696 & 0.138271 & 1.032004 & 0.3038 \\
\hline LNDDS(-1) & 0.021605 & 0.012467 & -1.732942 & 0.0853 \\
\hline LNEDS(-1) & -0.021528 & 0.010532 & 2.043999 & 0.0481 \\
\hline C(6) & 0.040763 & \multicolumn{2}{l}{} \\
\hline
\end{tabular}

R-Square $=0.620578$ "Durbin Watson $(\mathrm{DW})=1.831372$ "

F-Statistic $=4.713999$ Prob (F-Statistic) $=$ "0.001" 
4.2 Granger Causality Test

\begin{tabular}{|c|c|c|c|}
\hline Null Hypothesis & Obs & F-Statistic & Prob \\
\hline $\begin{array}{l}\text { "LNDDS" "does not Granger Cause" } \\
\text { "LNRGDP" }\end{array}$ & “53” & "1.05051" & “0.3103” \\
\hline $\begin{array}{l}\text { "LNRGDP” "does not Granger Cause" } \\
\text { "LNDDS" }\end{array}$ & & "10.3472" & “0.0023” \\
\hline $\begin{array}{l}\text { "LNEDS" "does not Granger Cause" } \\
\text { "LNRGDP" }\end{array}$ & “53” & "1.28153" & “0.2630” \\
\hline $\begin{array}{l}\text { "LNRGDP" "does not Granger Cause" } \\
\text { "LNEDS" }\end{array}$ & & “4.22999” & “0.0450” \\
\hline “LNEDS” “does not Granger Cause” "LNDDS” & “53” & "11.6330" & “0.0013” \\
\hline “LNDDS” “does not Granger Cause” “LNEDS” & & "13.0132" & “0.0007” \\
\hline
\end{tabular}

Table 5: Granger Causality Test Results

4.3. Post Estimation Diagnostic Tests

\begin{tabular}{|c|c|c|}
\hline Lags & LM-Statistic & Prob \\
\hline 1 & 20.23494 & 0.2098 \\
\hline 2 & 17.61191 & 0.3471 \\
\hline
\end{tabular}

Table 6: Serial Correlation LMTest Results

"Probs from chi-square with $16 \mathrm{df} "$

4.4. Normality Test

Jarque -Bera Test was used to test the normality of the residuals in the model. The findings of the Jarque-Bera Test are presented in table 7 below:

\begin{tabular}{|c|c|c|c|}
\hline Component & Jarque-Bera & df & Prob \\
\hline LNGDP(1) & 5.732714 & 2 & 0.353986 \\
\hline LNEDS(2) & 0.341244 & 2 & 0.065843 \\
\hline LNDDS(3) & 0.534413 & 2 & 0.057205 \\
\hline Joint & 5.342249 & 6 & 0.069174 \\
\hline
\end{tabular}

Table 7: Jarque-Bera Normality Test Results

\subsection{Heteroscedasticity Test}

Residual Heteroscedasticity test was employed to test if the residuals in the model are homoscedastic. The result of Heteroscedasticity test is indicated in table 8 below:

\begin{tabular}{|c|c|c|}
\hline Chi-sq & df & Prob \\
\hline 73.41904 & 48 & 0.10574 \\
\hline
\end{tabular}

Table 8: Residual Heteroskedasticity

Test (Level and Square)

\section{Discussion of Results}

\subsection{Unit Root Test}

From the result presented in table 1 above, we cannot reject the null hypothesis that the variables have unit root at level. This is because ADF test statistics for variables in absolute form is less than the t- statistics at both $5 \%$ and $10 \%$ level of significance implying that variables are not stationary and integrated of order one (1) I (1).

At first difference, the null hypothesis is rejected and instead the alternative hypothesis is accepted. This is because the $\mathrm{ADF}$ test statistic is greater in "absolute form" is greater than the t-statistics for variables at $5 \%$ and $10 \%$ level of significance. This suggests that at first Difference, variables are stationary and integrated of order one (1). 


\subsection{Johansen Cointegration Test}

From the above results presented in table 2, Trace test and Maximum Eigen test suggests that there is one cointegration equation suggesting that there is long - run relationship among variables. The normalized co-integration coefficient was used to interpret long run elasticity of dependent and independent variables. In this study, we normalized LNRGDP with respect to LNEDS and LNDDS.

From the result presented in table 3, long run normalized equation can written as follows:

$\operatorname{lnRGPDP}_{\mathrm{t}}=1.051383 \ln \mathrm{NEDS}_{\mathrm{t}}+1.214582 \operatorname{lnDDS} \mathrm{t}_{\mathrm{t}} \ldots \ldots \ldots . \mathrm{EQ} 3$

Given that the variables are expressed in log form interpretation of the results can be done in elasticities. From the results in table 19, LNEDS has negative long run relationship with LNRGDP while LNDDS has a positive long- run relationship with LNRGDP. The results also indicate coefficients are statistically significant at $5 \%$ level of significance.

Interpreting the above results, we can "say that a 10\% increase in LNEDS bring about $10.5 \%$ decrease in "LNRGDP" while a 10\% increase in "LNDDS bring about a 12.1\% increase in "LNRGDP" holding other factors "constant.

In the short-run, adjustment parameter coefficient indicates co-movement among variables in the short run". "From table 24 above the short run adjustment parameter equation can be written as follows:

$\Delta \operatorname{lnRGDP}=-0.407441 \Delta \operatorname{lnDDS}-0.228909 \Delta \ln N E D S \ldots \ldots \ldots . . \mathrm{EQ} 4$

The adjustment coefficient D(LNEDS) has downward speed of adjustment of $22.89 \%$ towards long-run equilibrium, while D(LNDDS) has upward speed of adjustment $40.74 \%$ towards long- run equilibrium in case of any disequilibrium. The D(LNGDP) has upward speed of adjustment of $2.08 \%$ in the short run toward long- run equilibrium state.

From the results presented in table 4 above, "the long run equation" for public debt service model was expressed as follows:

$\operatorname{lnRGPD} \mathrm{t}_{\mathrm{t}}=-15.24775+1.051383 \operatorname{lnDDS} \mathrm{t}_{\mathrm{t}}-1.214582 \ln \mathrm{EDS}_{\mathrm{t}} \ldots \ldots \ldots \ldots \mathrm{EQ} 5$

On interpretation, the coefficient signs are reversed, meaning that negative signs change to positive signs. From the above table 25, 10\% increase in LNDDS brings about 10.51\% increase in LNRGDP in the long -run while 10\% increase in LNEDS bring about $12.14 \%$ decrease in LNRGDP in the long-run holding other factors constant.

Based on the result presented in table 25 above, the short run equation for public debt service model was expressed as follows:

$\Delta \operatorname{lnRGDP} \mathrm{t}_{\mathrm{t}-1}=-0.020881 \mathrm{ECT}_{\mathrm{t}-1}+0.021605 \Delta \operatorname{lnDDS}_{\mathrm{t}-1}-0.021528 \Delta \ln \mathrm{EDS}_{\mathrm{t}-1}+0.040763 \ldots \mathrm{EQ6}$

In light of this result the coefficient of ECT $(1)==^{\prime \prime}-0.020881$ " and statistically significant at $5 \%$ level of significance with pvalue $0.048<0.05$ critical value. The negative sign on ECT (1) coefficient indicate that there is long- run convergence of the model.

"ECT(1) =-0.020881 indicates the speed of adjustment amid short run dynamics and the long run equilibrium is $2.088 \%$," thus correcting any deviations of the short run dynamics to its long- run equilibrium by $2.088 \%$ annually. It can also be said that the previous year deviation from long run equilibrium is corrected in the current period at an adjustment speed of $2.088 \%$ holding other factors constant.

"In the short run, 10\% increase in LNDDS brings about $2.16 \%$ increase in LNRGDP" "in the short-run holding other factors constant." "On the other hand, a 10\% increase in LNEDS brings about 2.15\% decrease in LNRGDP," "in the short- run holding other factors constant."

"The coefficient of multiple determination $\left(\mathrm{R}^{2}\right)$ value $=0.620578$," "this indicated that about $62.05 \%$ change in LNRGDP in the model can be accounted for by the explanatory variables LNEDS and LNDDS, while $38 \%$ can be attributed to other factors outside the model. F- Statistics $=4.713999$ with P-value $=0.001$ which is less than 0.05 critical value showing that explanatory variables jointly influence dependent variable "significantly at $5 \%$ level of significance. The Durbin Watson (DW) statistic $=1.831372$ indicate that there is no serial/ autocorrelation in the model.

\subsection{Granger Causality Test}

The negative sign and statistical significance of the error correction term (ECT) indicated that there is causality among variables LNRGDP, LNEDS and LNDDS. To explain the direction of causality among the variables in the model Granger causality Test was employed to test the direction of causality in the model.

Inferring from the result in table 5 above, "there is unidirectional causality running from LDDS to LNRGDP, with P value= "0.3103 >0.05. There is another unidirectional causality running from LNEDS to LNRGDP given that F-statistic Probability value $=0.2630>0.05$ at $5 \%$ level of significance.

\subsection{Serial Correlation LMTest}

To determine whether residuals of the model are not serially correlated, "LM Test was employed". From the results presented in table 6, "the null hypothesis "of no serial correlation" "is accepted because LM statistic P value" $=" 0.2095$ " ">0.05," "at $5 \%$ level of significance". This implies that there is no serial correlation in the model.

\subsection{Jarque-Bera Normality Test}

From the result presented in table 7 above, null hypothesis that residuals are multivariate normal is accepted at $5 \%$ level of significance. "LNRGDP", "LNEDS" and "LNDDS" have p-value greater than 0.05 critical value" "at 5\% level of significance" "implying the residual in the model are normally distributed. 


\subsection{Heteroscedasticity Test}

From the result presented in table 8, null hypothesis that residuals are homoscedastic was accepted given that the $p$-value $=0.10574>0.05$ critical value at $5 \%$ significance level. This confirmed that the model is homoscedastic.

In general, foreign debt service has deleterious association with GDP growth, while domestic debt service has affirmative effect on GDP growth.

In the short-run domestic debt, service has affirmative effect on the GDP growth, while foreign debt service has negative effect on economic growth in Kenya.

"The findings are consistent with (Nwanne, 2018; Molonko, Jagongo \& Omagwa, 2018; Otieno, 2015; Ebi \&Imoke, 2017)." "These studies have found out that foreign debt service has a deleterious relationship with GDP growth while domestic debt service has positive connection with GDP growth."

\subsection{Summary of Findings}

The study empirically examined the relationship between public debt service and economic growth in Kenya from 1980 -2017. The study made use of RGDP as a proxy measure of National output. "The main" "independent variables were," "external debt service" and "domestic debt service." The study applied stationarity test, cointegration test and VECM. "The results of this study indicate that:"

- "Foreign debt service has a statistically significant deleterious association with RGDP in Kenya in" "long run" and "short run."

- "Domestic debt service has a statistically significant positive connection with RGDP in Kenya in the" "longrun" and "short-run".

- There is a "unidirectional causal relationship" "running from domestic Debt Service to Real Gross Domestic Product (RGDP) in Kenya".

\section{Recommendations}

Deducing from findings in the study, "the study recommends that the government should take up sustainable external debt so that the country can spend less on external debt service". "With long -run inverse relationship between external debts on economic growth in Kenya". "It will be prudent to manage the country's external debt in such a way that it will be sustainable in terms" of repayment cost and allocate the borrowed funds on capital projects that boost the economic prosperity of the country.

\section{Conclusions}

The study tested the connection between debt service and RGDP growth in Kenya from 1980-2017." The applied VECM as a tool to analyze data. "The variables of the study were RGDP, EDS and DDS." "The results of the study revealed that EDS has a significant inverse relationship with RGDP growth in Kenya." The outcome of this is that Kenya has ended with huge foreign debt stock and if not taken seriously could result into instability.

Domestic debt service has a significant positive relationship with RGDP growth" in Kenya during the period under study. "There is a unidirectional causality running from domestic debt service to RGDP. The study recommends that the government should manage the public debt stock in order to manage the public debt service optimally.

\section{References}

i. Ezeabasili, V. N., Isu, H. O., \& Mojekwu, J. N. (2011).“Nigeria's foreign debt and GDP growth”: "an error correction Model". "International Journal of Business and Management," "6(5)","156-170".

ii. "Adesola”, W. A. (2009). "Debt servicing and GDP growth in Nigeria:" "An empirical investigation". "Global Journal of social sciences",8(2)

iii. Mencinger, J., Aristovnik, A., \&Verbic, M. "(2014)". "The effect of growing public debt on GDP growth in the European Union". "Amfiteatru" "Economic Journal”, 16(35), 403-414.

iv. Babu, J. O., Kiprop, S., Kalio, A. M., \& Gisore, M. (2015). "Effect of domestic debt on GDP growth" "in the east African community". American Journal of Research Communication, 3(9), 73-95.

v. Alcidi, C., \& Giovannini, A. (2015). "The Cost of Servicing Greece's Debt: A Sisyphean task? CEPS Commentary", 4 February 2015. Policy Paper.

vi. Al-Zeaud, H.A. (2014). "Public debt and GDP growth": "An empirical assessment”. "European Scientific Journal, ESJ, $10(4) "$.

vii. Apergis, N., \& Cooray, A. (2016). "Debt uncertainty" and "GDP growth": "evidence" "from five highly indebted Eurozone countries". Applied Economics Letters, 23(3), "171-174".

viii. Bua, G., Pradelli, J., \& Presbitero, A. F. (2014). "Domestic public debt in Low-Income Countries": "Trends and structure. Geneva": "The World Bank. Retrieved from": elibrary.worldbank.org.

ix. Cholifihani, M. (2008). "Cointegration analysis of government debt service and GDP growth in Indonesia”. "Journal of Management and social sciences", 4(2), 68-81.

x. Ebi, B. O., \& Imoke, I. D. (2017). "Public debt carrying capacity and debt transmission channels:" "The Nigerian Experience." "International Journal of Economics and Financial Issues," 7(5), 41-52.

xi. Huang, Y., Panizza, U., \& Varghese, R. (2018). "Does public debt crowd out corporate investment". International evidence. Retrieved from: https:/ / papers.ssrn.com/ sol3/ papers.cfm?abstract id=3178102

xii. Hukkinen, J., \& Viren, M. (2017). How toxic is public debt? International Journal of Public Policy, 13(1-2), 53-68. 
xiii. Kalemli-Özcan, Ș., Reinhart, C., \& Rogoff, K. (2016). Sovereign debt and financial crises: theory and historical evidence. Journal of the European Economic Association, 14(1), 1-6.

xiv. Karagol, E. (2012). "The causality analysis" "of external debt service and GNP in Turkey:" "Central Bank Review," 2(1), 39-64.

xv. Mahmoud, L. (2015). "The Function of Foreign Debt on GDP growth:" "Evidence from Mauritania." "International Journal of Economics \& Management Sciences," 4(4), 1-6.

xvi. Manik, N., \& Khan, N. A. (2018). "Government debt and GDP growth in India”: In Challenges and Issues in Indian Fiscal Federalism (pp. 123-142). Springer, Singapore.

xvii. Molonko, B., Jagongo, A., \& Omagwa, J. (2018). "Debt servicing and sectoral GDP growth in Kenya". "Applied Economics and Finance, 5(3), 100-107".

xviii. Muli, J. M., \& Ocharo, K. N. (2018). “External debt servicing and Current account balance in Kenya." "International Journal of Development and Sustainability," 7(5), 1688-1710.

xix. Nwanne, T. F. I. (2018). "Influence of debt servicing and GDP growth in Nigeria." "International "Journal of Economics and Finance," "7(9), "278-286.

xx. Omotosho, B. S., Bawa, S., \& Doguwa, S. I. (2016). "Determining the optimal public debt threshold for Nigeria." CBN Journal of Applied Statistics, 7(2), 1-25.

xxi. Otieno, M. (2015). Total Debt Servicing and Macroeconomic Performance in Kenya. Unpublished MSc thesis, Nairobi: Kenyatta University.

xxii. Owusu-Nantwi, V., \& Erickson, C. (2016). Government debt and GDP growth in Ghana. African Development Review, 28(1), 116-126.

xxiii. Ryan, T., \& Maana, I. (2014). An assessment of Kenya's public debt dynamics and sustainability. Nairobi: Central Bank of Kenya.

xxiv. Saxena, S. P., \& Shanker, I. (2018). Foreign Debt and GDP Growth in India. Journal of Social Science Asia, 4(1), 1525.

xxv. Siddique, A., Selvanathan, E. A., \& Selvanathan, S. ("2015”). "The effect of foreign debt on GDP growth:" "empirical evidence from highly indebted poor countries." "University of Western Australia, Economics".

xxvi. Upreti, P. (2015). "Factors affecting economic growth in developing Countries." "Major Themes in Economics," 17(1), 37-54.

xxvii. Shrestha, M. B., \& Bhatta, G. R. (2018). Selecting appropriate methodological framework for time series data analysis. "The Journal of Finance and Data Science", 4(2), 71-89.

xxviii. Boldeanu, F. T., \& Tache, I. (2016). The financial system of the EU and the Capital Markets Union. European Research Studies, 19(1), 59. 